\title{
RFLP analysis of the rRNA operon of a Brazilian collection of bradyrhizobial strains from 33 legume species
}

\author{
Mariana Gomes Germano, Pâmela Menna, Fabio Luis Mostasso \\ and Mariangela Hungria \\ Embrapa Soja, Cx. Postal 231, 86001-970, Londrina, PR, Brazil
}

Correspondence

Mariangela Hungria hungria@cnpso.embrapa.br or hungria@sercomtel.com.br

\section{INTRODUCTION}

The Leguminosae (known as the Fabaceae in the USA) is one of the largest families of plants, with over 18000 species classified into around 650 genera, representing approximately one-twelfth of all known flowering plants and

Published online ahead of print on 18 November 2005 as DOI 10.1099/ijs.0.02917-0.

Abbreviation: IGS, intergenic spacer.

Individual cluster analysis of PCR-RFLP products from the $16 \mathrm{~S}$ and $23 S$ rRNA genes and the 16S-23S IGS and details of the origins of the strains used and classification of their host species are available as supplementary material in IJSEM Online.
Genetic diversity in tropical rhizobial species is still poorly known. With the aim of increasing this knowledge, three ribosomal regions of 119 strains belonging to the official Brazilian culture collection of rhizobia and classified as Bradyrhizobium based on morphological and physiological characteristics in vitro were analysed by RFLP-PCR. The strains were isolated from 33 legume species, representing nine tribes and all three subfamilies; they all form very effective $\mathrm{N}_{2}$-fixing nodules and 43 of them are recommended for use in Brazilian commercial inoculants as the most effective for their hosts. For the 16S rRNA gene, type and reference strains of Bradyrhizobium japonicum fell into two major clusters, joined at a level of similarity of $50 \%$, which included 52 strains, $90 \%$ of which were isolated from soybean. Two other clusters, joined at a similarity of $53 \%$, included reference strains of Bradyrhizobium elkanii, but not USDA $76^{\top}$; furthermore, two other major clusters were identified and all strains were clustered at a final level of similarity of only $28 \%$. For the intergenic spacer (IGS) between genes coding for the $16 \mathrm{~S}$ and $23 \mathrm{~S}$ rRNA, strains were clustered at a final level of similarity of $27 \%$. Reference strains of $B$. japonicum fell into a major group with 51 strains, $84 \%$ isolated from soybean, with a similarity of $59 \%$, while strains of B. elkanii fell into another major group, with a similarity of $55 \%$, clustering 44 strains, $59 \%$ of which were isolated from hosts other than soybean. New clusters were also observed for the IGS region. The largest number of differences was detected in the analysis of the 23S rRNA gene, and 16 groups and isolated strains were joined at a very low level of similarity (16\%). In a combined analysis with the three ribosomal regions, the majority of strains isolated from soybean clustered with a similarity of $54 \%$ with type and reference strains of $B$. japonicum, while most strains isolated from Brazilian indigenous legume species grouped with $B$. elkanii at a level of similarity of $46 \%$. All strains were clustered at a very low level of similarity ( $27 \%$ ), and at least two new clusters were clearly defined. These new clusters might be related to intraspecific differences or to novel subspecies, or even to novel species; indeed, strains from one of these clusters show higher $16 \mathrm{~S}$ rRNA gene sequence similarity to members of the genus Burkholderia. The results obtained in this study emphasize the high level of diversity of symbiotic diazotrophic bacteria in the tropics that still remains to be determined. occupying nearly all terrestrial biomes (Polhill \& Raven, 1981). Many species within this family are capable of establishing symbioses with a group of bacteria collectively called rhizobia, of which the most important feature is the capacity for fixing atmospheric nitrogen $\left(\mathrm{N}_{2}\right)$ (Allen \& Allen, 1981).

Until 1982, all bacteria isolated from root nodules were classified in the genus Rhizobium, and speciation was based on the formation of nodules with certain host plants, establishing the 'cross-inoculation group' concept (Fred et al., 1932; Jordan, 1982). Based on morphological and physiological patterns, the bacteria were then split into the genera Bradyrhizobium, which included relatively slow growers 
that produced an alkaline reaction in culture medium with mannitol as carbon source, and Rhizobium, which contained fast-growing acid producers (Jordan, 1982, 1984). Initially, Bradyrhizobium japonicum was the only described species within the genus (Jordan, 1982, 1984), but reports of a large genetic and physiological variability among strains that nodulate soybean (Glycine max) led to the description of Bradyrhizobium elkanii a few years later (Kuykendall et al., 1992). Thereafter, other species were described: Bradyrhizobium liaoningense, extra-slowly growing rhizobia that nodulate primitive and modern soybean genotypes (Xu et al., 1995), Bradyrhizobium yuanmingense, the symbiont of Lespedeza spp., a legume that grows in the northern hemisphere (Yao et al., 2002), Bradyrhizobium betae, an endophyte that causes gall-like deformities on sugar beet (Beta vulgaris) and does not nodulate legumes (Rivas et al., 2004), and Bradyrhizobium canariense, a symbiont of genistoid legumes from the Canary Islands (Vinuesa et al., 2005a).

Ribosomal sequences, with the emphasis on the region that encodes the 16S rRNA, have become the tool of choice in molecular taxonomy for tracing bacterial phylogenies (Woese, 1987; Weisburg et al., 1991; Ludwig \& Schleifer, 1994; Garrity \& Holt, 2001). Partial or complete 16S rRNA gene sequences, which have also been used extensively for studying the phylogeny of rhizobia (e.g. Young et al., 1991; Oyaizu et al., 1992; Yanagi \& Yamasato, 1993; van Rossum et al., 1995; Urtz \& Elkan, 1996; Moreira et al., 1998; Vinuesa et al., 1998; Wang et al., 1999; Chen et al., 2000; JaraboLorenzo et al., 2000), have contributed to the recent descriptions of four new genera and several rhizobial species. However, there are reports showing that, despite a high level of diversity in morphological, physiological and genetic properties, diversity is low in the $16 \mathrm{~S}$ rRNA gene sequences of strains of Bradyrhizobium investigated so far (So et al., 1994, Urtz \& Elkan, 1996; Molouba et al., 1999; Vinuesa et al., 1998; Chen et al., 2000; van Berkum \& Fuhrmann, 2000; Willems et al., 2001; Qian et al., 2003).

The $23 \mathrm{~S}$ rRNA is a long fragment of about $2 \cdot 3 \mathrm{~kb}$; it therefore contains more information than the $16 \mathrm{~S}$ rRNA and has proven to be useful in the speciation of several genera of bacteria (Ludwig \& Schleifer, 1994), including rhizobia (Tesfaye et al., 1997; Terefework et al., 1998; Tesfaye \& Holl, 1998; Qian et al., 2003). Furthermore, as the rate of sequence change seems to be faster in the $23 \mathrm{~S}$ rRNA than in the 16S rRNA gene (Olsen \& Woese, 1993), the former may be more valuable for delineating close relationships (Wang \& Martínez-Romero, 2000).

When bacterial speciation is not clarified by $16 \mathrm{~S}$ rRNA gene sequencing, analysis of sequences of the 16S-23S rRNA intergenic spacer (IGS) has also proven to be useful, as the usually long sequence and the greater variability make the region particularly interesting for phylogenetic studies (Laguerre et al., 1996; Vinuesa et al., 1998; DoignonBourcier et al., 2000; van Berkum \& Fuhrmann, 2000; Willems et al., 2001).
Sequencing analysis of ribosomal genes of several strains can be very expensive; however, PCR-based locus-specific RFLP associated with ribosomal genes may be convenient for phylogenetic studies, generally showing high reproducibility and good agreement with partial or complete gene sequencing (Laguerre et al., 1994, 1996; Vinuesa et al., 1998; Wang et al., 1999; Abaidoo et al., 2000; Jarabo-Lorenzo et al., 2000).

Although it has been suggested that Bradyrhizobium is the ancestor of all rhizobia (Norris, 1965; Provorov \& Vorob'ev, 2000; Wang \& Martínez-Romero, 2000) and strains have been isolated from a variety of legumes distributed worldwide, most studies on diversity and genetics have been performed with fast-growing rhizobia. Furthermore, as has been pointed out since the pioneering studies of ribosomal genes, it seems that there are many more varieties of rhizobia in the tropics and subtropics than in temperate regions (Oyaizu et al., 1992; Vinuesa et al., 1998). Indeed, bradyrhizobia seem to represent the majority of isolates from leguminous trees in Brazilian tropical forests (Moreira, 1991, 2000). In addition, a high level of diversity among strains has been reported in a few studies performed in South America (Moreira et al., 1993; Urtz \& Elkan, 1996; Chen et al., 2000; Fernandes et al., 2003; Hara, 2003; Menna, 2005). That diversity deserves more investigation; therefore, in this study, RFLP of PCR-amplified $16 \mathrm{~S}$ and $23 \mathrm{~S}$ rRNA genes and of the IGS was used to characterize the level of diversity among 119 strains, capable of effectively nodulating several leguminous species and most of tropical origin, from the Brazilian Rhizobium Culture Collection SEMIA (Seção de Microbiologia Agrícola) (IBP World Catalogue of Rhizobium Collections, no. 443 in the WFCC World Data Center on Micro-organisms).

\section{METHODS}

Strains. One hundred and five strains from the Brazilian Rhizobium Culture Collection SEMIA, classified as Bradyrhizobium in the catalogue of FEPAGRO-MIRCEN [Fundação Estadual de Pesquisa Agropecuária (Rio Grande do Sul, Brazil) Microbiological Resources Center] (FEPAGRO, 1999) were used in this study. Information about the original source of the strains, the origin of the strains and their numbers in other collections is available in Supplementary Table S1 available in IJSEM Online. The strains were classified in the catalogue of FEPAGRO (1999) as Bradyrhizobium based on their host specificity and ability to produce an alkaline reaction in YMB medium (Vincent, 1970). After receipt from FEPAGRO, they were characterized again in YMB after Vincent (1970) and stocks were prepared on YM agar and kept at $-70{ }^{\circ} \mathrm{C}$ (in $30 \%$ glycerol) and at $4{ }^{\circ} \mathrm{C}$ (working cultures). Three other strains from the north-eastern region of Brazil were included, R 17, R 35 and R 45, classified as Bradyrhizobium based on RFLP-PCR of the 16S and 23S rRNA and IGS and on the partial sequence of the 16S rRNA gene (Fernandes et al., 2003). Five rhizobia from the Amazon region showing physiological properties of Bradyrhizobium (Hara, 2003) and four strains isolated from soybean nodules in Paraguay, with 16S rRNA gene sequences showing high similarity to B. japonicum (PRY 40 and PRY 42) and B. elkanii (PRY 52 and PRY 49) (Chen et al., 2000), were also included. Finally, B. elkanii USDA $76^{\mathrm{T}}$ and Bradyrhizobium sp. BTAi 1 were included, giving a total of 119 strains. 
Description of type and reference strains. Type strains included were $B$. japonicum USDA $6^{\mathrm{T}}\left(=\right.$ SEMIA $\left.5056^{\mathrm{T}}\right)$, provided by FEPAGRO, and $B$. elkanii USDA $76^{\mathrm{T}}$, provided by the US Department of Agriculture (USDA). Strain BTAi 1 was included as an outgroup on the basis of its distinctive 16S RNA gene sequence (Willems et al., 2001) and was also provided by the USDA. Other B. japonicum reference strains included SEMIA 566, SEMIA 586 (=CB 1809), their natural variants SEMIA 5079 (=CPAC 15) and SEMIA 5080 (=CPAC 7), respectively, both of which have been used in Brazilian commercial inoculants for soybean since 1992 (Nishi et al., 1996; Chueire et al., 2003), and SEMIA 5085, used in soybean commercial inoculants in Argentina, all of which had their taxonomic position confirmed by the sequencing of the whole $16 \mathrm{~S}$ rRNA gene (Chueire et al., 2003). B. elkanii reference strains included SEMIA 587 and SEMIA $5019(=29 \mathrm{w})$, both of which have also been used in Brazilian commercial inoculants for soybean since 1979 (Nishi et al., 1996; Chueire et al., 2003); their 16S rRNA genes have also been sequenced (Chueire et al., 2003).

DNA extraction. Total genomic DNA of each strain was extracted from bacterial batch cultures grown in YMB until late exponential phase $\left(10^{9}\right.$ cells $\left.\mathrm{ml}^{-1}\right)$. Extraction of DNA was performed as described previously (Fernandes et al., 2003). To obtain clean DNA samples, the extraction procedure included the addition, for each $400 \mu \mathrm{l}$ bacterial culture resuspended in TE 50/20, of $50 \mu \mathrm{l} 10 \%$ SDS, $5 \mu \mathrm{l}$ proteinase $\mathrm{K}\left(20 \mathrm{mg} \mathrm{ml}^{-1}\right), 10 \mu \mathrm{l}$ lysozyme $\left(5 \mathrm{mg} \mathrm{ml}^{-1}\right)$ and $2 \mu \mathrm{l}$ RNase $\left(10 \mathrm{mg} \mathrm{ml}^{-1}\right)$.

RFLP of PCR-amplified DNA region encoding the 165 rRNA. Three replicates of DNA from each bacterium were used for amplification with the universal primers described by Weisburg et al. (1991), fD1 ( $5^{\prime}$-CCGAATTCGTCGACAACAGAGTTTGATCCTGGCTCAG-3') and rD1 ( $3^{\prime}$-CCCGGGATCCAAGCTTAAGGAGGTGATCCAGCC-5'). Each replicate contained, in a volume of $50 \mu \mathrm{l}$ (final concentration in parentheses), dNTPs (300 $\mu \mathrm{M}$ of each), $5 \cdot 0 \mu \mathrm{l} 10 \times$ buffer, $\mathrm{MgCl}_{2}$ $(1.5 \mathrm{mM})$, primers (15 pmol of each), Taq DNA polymerase $(1 \cdot 25 \mathrm{U})$, DNA (20 ng), DMSO (5\%) and sterile Milli-Q water to complete the final volume. The reaction was carried out in a PTC 200 thermocycler (MJ Research Inc.), using an initial cycle of denaturation at $95^{\circ} \mathrm{C}$ for $2 \mathrm{~min}, 30$ cycles of denaturation at $94^{\circ} \mathrm{C}$ for $15 \mathrm{~s}$ and $93^{\circ} \mathrm{C}$ for $45 \mathrm{~s}$, annealing at $55^{\circ} \mathrm{C}$ for $45 \mathrm{~s}$ and extension at $72{ }^{\circ} \mathrm{C}$ for $2 \mathrm{~min}$ and a final extension cycle at $72{ }^{\circ} \mathrm{C}$ for $5 \mathrm{~min}$, with a final soak at $4{ }^{\circ} \mathrm{C}$.

The PCR products were then digested with three restriction endonucleases, CfoI, MspI and DdeI (Invitrogen Life Technologies), as recommended by the manufacturer. The fragments obtained were analysed by electrophoresis in a gel $(17 \times 11 \mathrm{~cm})$ with $3 \%$ agarose and carried out at $100 \mathrm{~V}$ for $4 \mathrm{~h}$. Gels were stained with ethidium bromide and photographed under UV light. The profiles obtained were confirmed in triplicate.

RFLP-PCR of the 235 rRNA region. Three replicates of the DNA of each strain were amplified with primers P3 (5'-CCGTGCGGGAAAGGTCAAAAGTAC-3') and P4 (5'-CCCGCTTAGATGCTTTCAGC-3'), described by Terefework et al. (1998), with the same PCR program described above. The PCR products were digested with three restriction endonucleases, HhaI (=CfoI), HaeIII and HinfI, as recommended by the manufacturer (Invitrogen Life Technologies). The fragments were visualized as described above and the profiles obtained were confirmed in triplicate.

RFLP-PCR of the 16S-23S rRNA IGS. Three replicates of the DNA of each strain were amplified with primers FGPS1490 (5'-TGCGGCTGGATCACCTCCTT-3') and FGPS132 (5'-CCGGGTTTCCCCATTCGG-3'), described by Laguerre et al. (1996). The reaction mixture contained, in a volume of $50 \mu \mathrm{l}$ (final concentration in parentheses): dNTPs $(200 \mu \mathrm{M}$ of each); $5 \cdot 0 \mu \mathrm{l} 10 \times$ buffer,
$\mathrm{MgCl}_{2}(1.5 \mathrm{mM})$, primers $(12 \cdot 5 \mathrm{pmol}$ of each), Taq DNA polymerase $(1 \cdot 0 \mathrm{U})$, DNA $(40 \mathrm{ng})$ and sterile Milli-Q water to complete the final volume. The PCR program was as follows: denaturation at $95^{\circ} \mathrm{C}$ for $3 \mathrm{~min}, 35$ cycles of denaturation at $94{ }^{\circ} \mathrm{C}$ for $1 \mathrm{~min}$, annealing at $55^{\circ} \mathrm{C}$ for $1 \mathrm{~min}$ and extension at $72{ }^{\circ} \mathrm{C}$ for $2 \mathrm{~min}$ followed by an extension cycle at $72{ }^{\circ} \mathrm{C}$ for $3 \mathrm{~min}$ and a final soak at $4{ }^{\circ} \mathrm{C}$. The PCR products were then digested with the restriction enzymes MspI, DdeI and HaeIII (Invitrogen Life Technologies) as recommended by the manufacturer. The fragments were visualized as described above and the profiles were confirmed in triplicate.

Cluster analyses. The sizes of the fragments in all analyses were normalized according to the size of the DNA markers, which were included on the left and right and in the centre of each gel. For the combined analysis of the three ribosomal regions with the respective enzymes, a combined profile of all the individual sets of restriction patterns was obtained. Cluster analyses were performed with the Bionumerics program version 1.50 (Applied Mathematics), using the UPGMA algorithm (unweighted pair-group method with arithmetic means) (Sneath \& Sokal, 1973) and the Jaccard coefficient. Analyses of each ribosomal region with three restriction enzymes and of the three combined ribosomal regions were performed in the Bionumerics program setting the position tolerance of the bands to 1,3 and $5 \%$, as well as utilizing the optimum values indicated for optimization and position tolerance in the Bionumerics program for each restriction enzyme. Increasing the position tolerance sometimes resulted in a smaller number of subclusters, and often bands that were different in one gel at 1 or $3 \%$ were similar at $5 \%$; however, the main clusters were always confirmed. We have thus decided to consider the optimum values indicated by the program for each region and enzyme, as follows (in parentheses are values of optimization; tolerance): $16 \mathrm{~S}$ rRNA with $C f o \mathrm{I}(0 ; 2 \cdot 25), M s p \mathrm{I}(0 \cdot 52 ; 0 \cdot 87)$ and DdeI (0; 0.87); IGS with MspI $(0 \cdot 44 ; 5 \cdot 67), D d e I(0 \cdot 47 ; 2 \cdot 25)$ and HaeIII $(0 \cdot 67 ; 2 \cdot 25) ; 23 \mathrm{~S}$ rRNA with HaeIII $(0 \cdot 43 ; 0 \cdot 37)$, HinfI $(0$; $3 \cdot 26)$ and HhaI $(0 \cdot 43 ; 0 \cdot 72)$.

\section{RESULTS}

The properties of all 119 strains were consistent with those of the genus Bradyrhizobium (Jordan, 1982, 1984). None of the strains showed the extra-slow growth of $B$. liaoningense (Xu et al., 1995) or the characteristics of either B. yuanmingense isolated from Lespedeza spp. (Yao et al., 2002) or B. canariense isolated from Chamaecystisus proliferus (Vinuesa et al., 2005a); therefore, type strains for those species were not included in this study. Strains used in this study were isolated from 33 legume species (Table 1 and Supplementary Table S1), representing nine tribes and all three subfamilies (Supplementary Table S2).

Amplification of the 16S rRNA gene always produced a single PCR product of about 1500 bp (data not shown). A high level of diversity was observed and bacteria were clustered in seven 'great groups' (GG) and 19 subgroups (SG) (Table 1; Supplementary Fig. S1). GG I clustered strains at $36.6 \%$ similarity and could be split into two subgroups and one isolated strain (SEMIA 658). Strains PRY 40 and 42 , within SG I, have previously been shown to exhibit $16 S$ rRNA gene sequence similarity to B. japonicum, whereas PRY 52 was genetically closer to B. elkanii (Chen et al., 2000). The other strains within GG I were isolated from various tropical legumes (Prosopis, Mimosa, Vigna and Lotononis). GG II included five subgroups (III-VII), at a 
Table 1. Strains included in this study and their positions in $16 \mathrm{~S}$ rRNA, IGS and $23 S$ rRNA RFLP-PCR cluster analysis and the combined analysis

Great groups (GG), groups (G) and subgroups (SG) in which each strain fell in each cluster analysis are indicated. Details of type and reference strains are given in Methods, and details of the origins of the strains are given in Supplementary Table S1. i, Isolated strain; NA, not amplified.

\begin{tabular}{|c|c|c|c|c|c|}
\hline Strain & Host plant & $\begin{array}{c}\text { 16S rRNA SG } \\
\text { (GG) }\end{array}$ & $\begin{array}{c}\text { IGS SG } \\
(\text { GG) }\end{array}$ & $\begin{array}{c}23 S \\
\text { rRNA G }\end{array}$ & $\begin{array}{c}\text { Combined SG } \\
(\mathrm{GG})\end{array}$ \\
\hline SEMIA $6169^{*}$ & Albizia falcataria & XIX (GG V) & VIII (GG II) & $\mathrm{V}$ & I (GG I) \\
\hline SEMIA $6175^{\star}$ & Pueraria phaseoloides & XIX (GG V) & VIII (GG II) & III & I (GG I) \\
\hline SEMIA $6208^{*}$ & Desmodium ovalifolium & XII (GG IV) & VIII (GG II) & III & I (GG I) \\
\hline SEMIA $6387^{\star}$ & Acacia auriculiformis & XIV (GG IV) & i (GG II) & III & I (GG I) \\
\hline SEMIA $6425^{\star}$ & Centrosema pubescens & XIX (GG V) & VII (GG II) & XIII & II (GG I) \\
\hline SEMIA 549 & Glycine max & XVIII (GG V) & VII (GG II) & XIII & II (GG I) \\
\hline B. elkanii SEMIA 5019* & Glycine max & XV (GG V) & VI (GG II) & VII & II (GG I) \\
\hline R 35 & Cajanus cajan & XVII (GG V) & VII (GG II) & $\mathrm{V}$ & III (GG I) \\
\hline R 17 & Vigna unguiculata & XVII (GG V) & VII (GG II) & $\mathrm{V}$ & III (GG I) \\
\hline SEMIA 5069 & Glycine max & XVII (GG V) & VII（GG II） & $\mathrm{V}$ & III (GG I) \\
\hline SEMIA $6053^{*}$ & Clitoria ternatea & XVII (GG V) & VII (GG II) & VII & III (GG I) \\
\hline SEMIA $6028^{\star}$ & Desmodium uncinatum & XVIII (GG V) & VII (GG II) & VII & III (GG I) \\
\hline SEMIA 590 & Glycine $\max$ & XVI (GG V) & VII (GG II) & $\mathrm{V}$ & IV (GG I) \\
\hline SEMIA 598 & Glycine $\max$ & XVI (GG V) & VII (GG II) & $\mathrm{V}$ & IV (GG I) \\
\hline B. elkanii SEMIA $587^{\star}$ & Glycine max & XVI (GG V) & VII (GG II) & $\mathrm{V}$ & IV (GG I) \\
\hline SEMIA $696^{*}$ & Desmodium uncinatum & XV (GG V) & VII (GG II) & VI & IV (GG I) \\
\hline SEMIA 5011 & Glycine max & XVI (GG V) & VII (GG II) & VI & IV (GG I) \\
\hline SEMIA 5012 & Glycine $\max$ & XVI (GG V) & VII (GG II) & $\mathrm{V}$ & IV (GG I) \\
\hline SEMIA 5016 & Glycine $\max$ & XVI (GG V) & VII (GG II) & VII & IV (GG I) \\
\hline SEMIA $662^{*}$ & Vigna unguiculata & XVI (GG V) & VII (GG II) & VI & IV (GG I) \\
\hline SEMIA $695^{\star}$ & Neonotonia wightii & XV (GG V) & VII (GG II) & VI & IV (GG I) \\
\hline SEMIA 5027 & Glycine $\max$ & XV (GG V) & VII (GG II) & VI & IV (GG I) \\
\hline SEMIA 5026 & Glycine max & XV (GG V) & VII (GG II) & VI & IV (GG I) \\
\hline SEMIA 5070 & Glycine max & XVII (GG V) & VII (GG II) & VI & i $($ GG I) \\
\hline SEMIA $6150^{*}$ & Acacia mearnsii & XVII (GG V) & VII (GG II) & III & V (GG I) \\
\hline SEMIA $6157^{\star}$ & Cajanus cajans & XII (GG IV) & VII (GG II) & VI & $\mathrm{V}(\mathrm{GG} \mathrm{I})$ \\
\hline SEMIA $6159^{*}$ & Enterolobium ellipticum & XII (GG IV) & VII (GG II) & III & $\mathrm{V}(\mathrm{GG} \mathrm{I})$ \\
\hline SEMIA $6158^{\star}$ & Crotalaria spectabilis & XII (GG IV) & VII (GG II) & II & V (GG I) \\
\hline SEMIA $6149^{*}$ & Galactia striata & XII (GG IV) & VII (GG II) & III & V (GG I) \\
\hline SEMIA 6093 & Aeschynomene americana & XIII (GG IV) & VII (GG II) & VI & $\mathrm{V}(\mathrm{GG} \mathrm{I})$ \\
\hline SEMIA 6099 & Dimorphandra exaltata & XIII (GG IV) & VII (GG II) & VI & V (GG I) \\
\hline SEMIA $6101^{\star}$ & Dalbergia nigra & XIII (GG IV) & VII (GG II) & VI & V (GG I) \\
\hline SEMIA $6145^{\star}$ & Crotalaria juncea & XVI (GG V) & VII (GG II) & VI & V (GG I) \\
\hline SEMIA $6146^{*}$ & Centrosema sp. & XIII (GG IV) & i (GG II) & III & $\mathrm{V}(\mathrm{GG} \mathrm{I})$ \\
\hline SEMIA $6148^{*}$ & Neonotonia wightii & XIII (GG IV) & i (GG II) & III & $\mathrm{V}(\mathrm{GG} \mathrm{I})$ \\
\hline SEMIA $6160^{*}$ & Albizia lebbek & XVII (GG V) & VII (GG II) & II & V (GG I) \\
\hline AM-01-517 & Stryphnodendron pulcherrimum & XVI (GG V) & VIII (GG II) & $\mathrm{V}$ & VI (GG I) \\
\hline AM-2-855 & Vigna unguiculata & XVI (GG V) & VIII (GG II) & XIII & VI (GG I) \\
\hline SEMIA 538 & Glycine max & XIII (GG IV) & VII (GG II) & XIII & VII (GG I) \\
\hline SEMIA 542 & Glycine $\max$ & X (GG III) & VI (GG II) & XIII & VII (GG I) \\
\hline SEMIA 577 & Glycine max & XVIII (GG V) & VII (GG II) & $\mathrm{V}$ & VII (GG I) \\
\hline SEMIA 501 & Glycine max & XVIII (GG V) & VII (GG II) & $\mathrm{V}$ & VII (GG I) \\
\hline R 45 & Cajanus cajan & XIV (GG IV) & VI (GG II) & XIII & i (GG I) \\
\hline SEMIA 562 & Glycine $\max$ & X (GG III) & $\mathrm{V}(\mathrm{GG} \mathrm{I})$ & XIV & VIII (GG I) \\
\hline SEMIA 565 & Glycine max & X (GG III) & VII (GG II) & XIV & VIII (GG I) \\
\hline SEMIA $6424^{*}$ & Centrosema pubescens & XIX (GG V) & VII (GG II) & XIII & i $($ GG I) \\
\hline B. elkanii USDA $76^{\mathrm{T}}$ & Glycine $\max$ & $\mathrm{i}$ & VII (GG II) & $\mathrm{XV}$ & i (GG I) \\
\hline SEMIA $6163^{*}$ & Acacia mearnsii & VI (GG II) & IV (GG I) & XII & IX (GG II) \\
\hline
\end{tabular}


Table 1. cont.

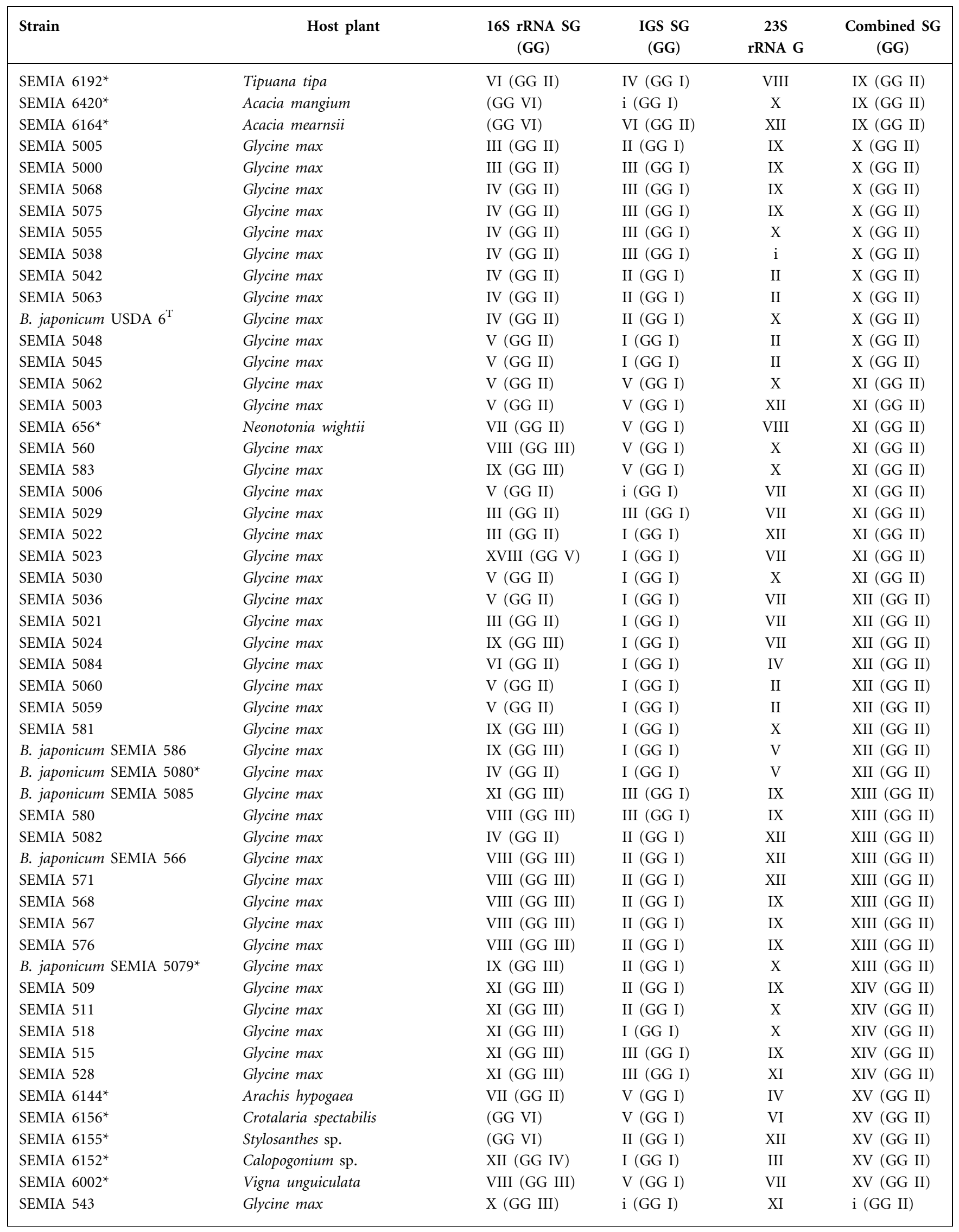


Table 1. cont.

\begin{tabular}{|c|c|c|c|c|c|}
\hline Strain & Host plant & $\begin{array}{c}\text { 16S rRNA SG } \\
(\mathrm{GG})\end{array}$ & $\begin{array}{l}\text { IGS SG } \\
\text { (GG) }\end{array}$ & $\begin{array}{c}23 S \\
\text { rRNA G }\end{array}$ & $\begin{array}{c}\text { Combined SG } \\
\text { (GG) }\end{array}$ \\
\hline SEMIA $6319^{*}$ & Arachis sp. & (GG VI) & $\mathrm{X}$ & II & $\mathrm{i}$ \\
\hline SEMIA 569 & Glycine $\max$ & $\mathrm{i}$ & i (GG I) & I & $\mathrm{i}$ \\
\hline SEMIA $658^{*}$ & Lotononis bainesii & i (GG I) & i (GG II) & $\mathrm{i}$ & $\mathrm{i}$ \\
\hline PRY 52 & Glycine max & II (GG I) & NA & I & (GG III) \\
\hline AM-Cp 17 & Vigna unguiculata & II (GG I) & i (GG II) & I & (GG III) \\
\hline PRY 42 & Glycine $\max$ & I (GG I) & NA & I & (GG III) \\
\hline PRY 40 & Glycine max & I (GG I) & i (GG I) & I & (GG III) \\
\hline Bradyrhizobium sp. BTAi 1 & Aechynomene indica & $\mathrm{i}$ & i (GG II) & $\mathrm{XV}$ & $\mathrm{i}$ \\
\hline PRY 49 & Glycine $\max$ & (GG VII) & IX & XVI & (GG IV) \\
\hline AM-P5 Abac & Vigna unguiculata & (GG VII) & $\mathrm{X}$ & XVI & (GG IV) \\
\hline AM-P2 Lima & Vigna unguiculata & (GG VII) & IX & XVI & (GG IV) \\
\hline
\end{tabular}

*Strain recommended for use in Brazilian commercial inoculants for that legume species.

level of similarity of $58 \cdot 7 \%$. Several strains within these subgroups showed complete profile similarity and all strains within SG III, IV and V, representing $82 \%$ of GG II, were isolated from soybean. B. japonicum strains SEMIA 5080 and $5056^{\mathrm{T}}\left(=\right.$ USDA $6^{\mathrm{T}}$ ) clustered into SG IV at $82 \cdot 6 \%$ similarity, while SG VI and VII included strains isolated from soybean, Tipuana, Acacia, Arachis and Neonotonia. GG III was split into four subgroups (VIII-XI) at a $59 \cdot 0 \%$ level of similarity and included 24 strains, all isolated from soybean except for SEMIA 6002 (from Vigna). GG III also included B. japonicum reference strains SEMIA 566, 586, 5079 and 5085 (Table 1; Supplementary Fig. S1). Therefore GG II and III clustered 52 strains, $90 \%$ of which were from soybean, including type and reference strains, with a similarity of $50 \%$. The great majority of strains isolated from tropical legume trees was positioned in GG IV, V and VI. GG IV contained 14 strains, only one (SEMIA 538) from soybean. The large GG V clustered 31 strains, 15 from soybean, including the B. elkanii reference strains SEMIA 5019 and SEMIA 587, which were positioned in SG XV and XVI, respectively. Within GG V, some strains showed complete similarity, e.g. four strains within SG XVI isolated from crotalaria, soybean and cowpea were similar to the commercial soybean strain SEMIA 587. GG IV and V grouped two reference B. elkanii strains with a similarity of $53 \cdot 1 \%$, but not USDA $76^{\mathrm{T}}$. Five strains were grouped at $51 \cdot 8 \%$ in GG VI, none of which were from soybean. Three quite dissimilar strains were joined to GG IV, V and VI, including B. elkanii USDA $76^{\mathrm{T}}$, at $32 \cdot 9 \%$ similarity (Table 1; Supplementary Fig. S1). GG VII included six strains clustered at $45 \cdot 2 \%$ similarity, none of which were from soybean. Finally, strain BTAi 1 was quite distinct from the other groups and joined them at a level of $27 \cdot 9 \%$ similarity (Table 1; Supplementary Fig. S1).

Amplification of the IGS resulted in one fragment with sizes ranging from 1200 to $1800 \mathrm{bp}$; five strains (SEMIA 695, $5060,5075,6146,6159)$ produced an extra fragment of 800 1500 bp (data not shown), while amplification failed with two others (PRY 42 and PRY 52). The fragments produced with the primers were larger than those obtained by Willems et al. (2001) and Doignon-Bourcier et al. (2000), but we have used different primers. Cluster analysis of the RFLP products of the IGS resulted in two main great groups and isolated strains that were joined at a final level of similarity of $26 \cdot 7 \%$ (Table 1; Supplementary Fig. S2). GG I was divided into five main subgroups, joined at a level of similarity of $58.6 \%$, and included type and reference strains of $B$. japonicum; six other strains were joined to this great group at a level of similarity of $37 \cdot 4 \%$. SG I included the $B$. japonicum reference strain SEMIA 5080 and its putative parent SEMIA 586, while SG II included B. japonicum SEMIA 5079 and its putative parent SEMIA 566, as well as the type strain, SEMIA $5056^{\mathrm{T}}$. Of the 40 strains in SG I, II and III, all but one from SG I (SEMIA 6152, from Calopogonium) and one from SG II (SEMIA 6155, from Stylosanthes) were isolated from soybean, while the two strains comprising SG IV and four of the nine strains of SG $\mathrm{V}$ came from other hosts. It is also noteworthy that three strains within SG V, SEMIA 6002, 6144 and 6156, showed complete similarity of profiles although isolated from different genera and tribes, Vigna (Phaseoleae), Arachis (Aeschynomeneae) and Crotalaria (Crotolarieae), respectively, all belonging to the subfamily Papilionoideae. All 
but one (SEMIA 6420) of the six isolated strains that were joined to GG I were isolated from soybean (Table 1; Supplementary Fig. S2). Type and reference strains of $B$. elkanii were positioned in SG VI, VII and VIII of GG II with a final level of similarity of $55 \cdot 1 \%$. Of the 44 strains within this group, 26 were isolated from legumes other than soybean. Nine other strains were joined to this group at a final level of similarity of only $44 \cdot 5 \%$, all isolated from legumes other than soybean, including the reference strain BTAi 1. GG I and II were joined at a level of similarity of $36 \%$. Finally, two other small subgroups clustered seven strains. Within SG IX, three strains isolated from Mimosa showed similarity of $89 \cdot 2 \%$ and were joined to soybean strain B. elkanii PRY 49 and to a cowpea strain at $36 \cdot 8 \%$ similarity. SG X included two strains isolated from Arachis and Vigna with a very low level of similarity $(33 \cdot 1 \%)$ (Table 1; Supplementary Fig. S2).

One fragment of about $2 \cdot 3 \mathrm{~kb}$ was obtained for all strains for the 23S rRNA region (data not shown). Analysis of the $23 \mathrm{~S}$ rRNA region resulted in the highest level of diversity observed in this study. Great groups were not observed in the cluster analysis; however, 16 groups $(\mathrm{G})$ were observed, as well as some isolated strains (Table 1; Supplementary Fig. S3). G I of the $23 \mathrm{~S}$ rRNA region joined eight strains at a very low level of similarity $(23 \cdot 6 \%)$. Four subclusters of pairs of strains were shown in G I: PRY 52 (Glycine)/AM-Cp 17 (Vigna) (65.5\%), PRY 42/PRY 40 (Glycine) $(78 \cdot 3 \%)$, SEMIA 6161 (Prosopis)/6165 (Mimosa) (49.8\%) and SEMIA 535/569 (Glycine) (50.0\% similarity). Nine strains were clustered in G II with a similarity of $50.6 \%$, six from soybean and three from species of the subfamilies Papilionoideae and Mimosoideae. Another nine strains were placed in G III at a level of similarity of $61.5 \%$, isolated from a wide range of host legumes. G IV included only two strains, from soybean and peanut, with a similarity of $72 \cdot 2 \%$. Although showing a higher level of similarity than many other groups $(78 \cdot 5 \%), \mathrm{G} \mathrm{V}$ was unusual, as it clustered reference strains of both B. elkanii (SEMIA 587) and B. japonicum (SEMIA 5080 and its putative parent SEMIA 586), together with ten other strains isolated from both soybean and other legumes. G VI joined 13 strains at a similarity of $80 \cdot 2 \%$, five of which were completely similar, although isolated from completely different hosts. Eleven strains were clustered in G VII at a level of similarity of $71.8 \%$; all but three had been isolated from soybean, including B. elkanii reference strain SEMIA 5019. G VIII joined only two strains $(65.5 \%$ similarity), isolated from Tipuana tipa and Neonotonia wightii, both from the Papilionoideae. Groups IX-XI were joined at $64 \cdot 5 \%$ similarity and included 24 strains, all but one (SEMIA 6420) of which had been isolated from soybean, including B. japonicum reference strains SEMIA 5085, 5079 and $5056^{\mathrm{T}}$, which were positioned in G IX and G X. G XII clustered $(65 \cdot 2 \%)$ five strains isolated from soybean, including reference strain $B$. japonicum SEMIA 566, as well as three strains isolated from other legumes. In addition, SEMIA 5038 showed high variability in the $23 \mathrm{~S}$ rRNA region and occupied an isolated position. Seven strains were clustered in G XIII with a similarity of $51 \cdot 1 \%$, isolated from four genera of the subfamily Papilionoideae (Glycine, Cajanus, Vigna and Centrosema), while G XIV included two soybean rhizobia (78 \% similarity). SEMIA 658 from Lotonis bainesii occupied an isolated position, while B. elkanii USDA $76^{\mathrm{T}}$ and BTAi 1 were clustered into $G X V$ with a very low level of similarity $(33.9 \%)$. The last group, G XVI, clustered six strains, three isolated from Mimosa, two isolated from Vigna in the Amazon region and PRY 49 from soybean nodules in Paraguay. Finally, SEMIA 6154, symbiont of Stylosanthes, joined the other clusters at a very low level of similarity, $15 \cdot 5 \%$ (Table 1 ; Supplementary Fig. S3). Analysis of the $23 \mathrm{~S}$ rRNA region therefore resulted in the largest number of differences in comparison with the 16S rRNA and IGS regions. When the 16S rRNA and IGS regions were compared with the $23 \mathrm{~S}$ rRNA region, in a few clusters the majority of the strains showed the properties of either B. japonicum (G IV, IX, X, XI) or B. elkanii (G III), but a predominance of strains showed mixed properties (G II, V, VII, XII, XIII, XIV). Furthermore, at least two groups (I and XV) were quite different from the others in the $23 \mathrm{~S}$ rRNA region and might represent novel species (Supplementary Fig. S3).

A dendrogram was built considering all three ribosomal regions, each with three restriction enzymes (Fig. 1). Furthermore, to help the comparison of the results obtained in the analysis of the 16S rRNA (Supplementary Fig. S1), IGS (Supplementary Fig. S2) and 23S rRNA (Supplementary Fig. S3), Table 1 was constructed and will be used here for description of the results. Analysis considering the three ribosomal regions resulted in four main great groups and six isolated strains, joined at a final level of similarity of $26.9 \%$ (Fig. 1 ).

Forty-seven strains were joined in GG I of the combined analysis with a similarity of $46.5 \%$ and included all reference and type strains of $B$. elkanii; GG I could be split into eight subgroups and four isolated strains (Fig. 1). Table 1 shows that 30 strains of GG I of the combined analysis had been clustered into GG V (composed of 31 strains) and 13 into GG IV (composed of 14 strains) in the 16S rRNA analysis; in addition, all strains within GG I of the combined analysis fell into GG II of the IGS analysis. However, the strains occupied different groups in the $23 \mathrm{~S}$ rRNA analysis, as follows (number of strains in the combined analysis followed by the percentage in relation to all strains within that group in the $23 \mathrm{~S}$ rRNA analysis): G II (2, $22 \%)$, III $(8,89 \%)$, V (11, 85\%), VI (12, $92 \%)$, VII (4, $36 \%)$, XIII (7, $100 \%)$, XIV (2, $100 \%)$ and XV (1, $50 \%)$. Furthermore, strains representing a large percentage of some groups of the 23S rRNA analysis (as those of G III, V, VI, XIII and XIV) were often positioned in different subgroups of the $16 \mathrm{~S}$ and IGS analyses. Reference strains of B. elkanii, SEMIA 587 and 5019, were positioned in GG V of the 16S rRNA analysis, GG II of the IGS analysis and G V and VII, respectively, of the $23 \mathrm{~S}$ rRNA analysis, while the type strain USDA $76^{\mathrm{T}}$ occupied an isolated position in the 


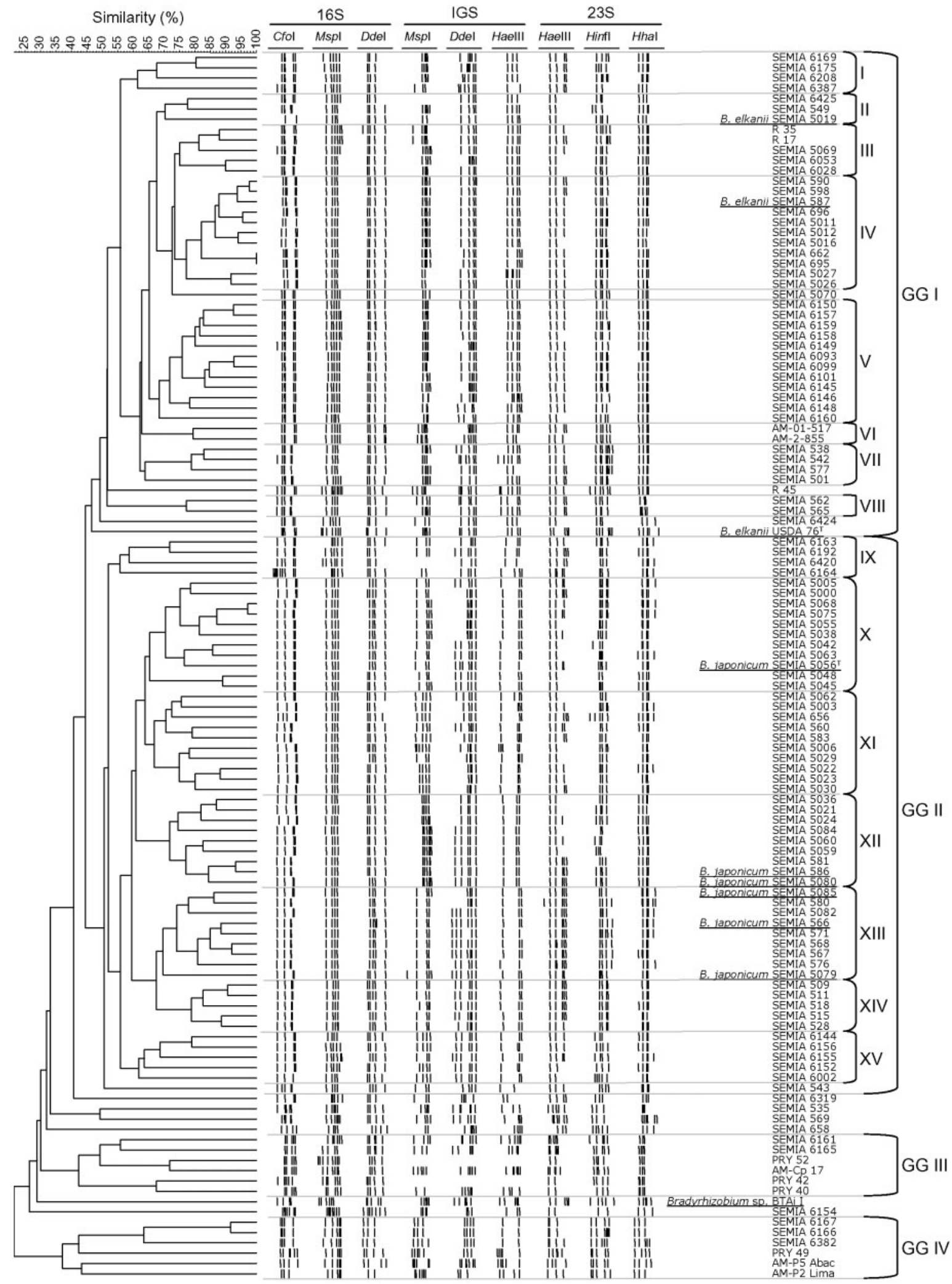

Fig. 1. Cluster analysis (UPGMA with the Jaccard coefficient, converted to percentage similarity) of products obtained by PCR-RFLP analysis of the 16S rRNA gene, IGS and 23S rRNA gene of bradyrhizobial strains, each with three restriction enzymes. Reference and type strains (underlined) are labelled and classified according to the sequencing analysis of the $16 S$ rRNA gene, as described in Methods. 
$16 \mathrm{~S}$ rRNA analysis but clustered in GG II in the IGS analysis and $\mathrm{G} \mathrm{XV}$ in the $23 \mathrm{~S}$ rRNA analysis (Table 1).

Although the results obtained in the combined analysis might indicate a clustering of the B. elkanii species, the detection of several subclusters, the low level of similarity joining the strains and the low similarity of the type strain to the other strains clearly show that the genetic variability detected in this study deserves further investigation. For example, at $61.8 \%$ similarity, SG I clustered four strains, SEMIA $6169,6175,6208$ and 6387, which were isolated from four different genera, Falcataria, Pueraria, Desmodium and Acacia, and were quite distinct from the other strains within GG I. SG IV clustered 11 strains, eight isolated from soybean, including reference strain SEMIA 587, while SG V included 12 strains, none from soybean, ten of them indigenous to Brazilian soils (Fig. 1).

GG II of the combined analysis could be split into seven subgroups and clustered 54 strains, including the type strain (SEMIA $5056^{\mathrm{T}}$ ) and reference strains (SEMIA 586, 5080, 5085, 566 and 5079) of B. japonicum, at a level of similarity of $51.4 \%$ (Fig. 1). Only ten were isolated from soybean, nine of which clustered into two subgroups, SG IX and XV. SG IX clustered four strains, three from Acacia (Mimosoideae) and one from Tipuana (Papilionoideae) (Fig. 1, Table 1); these strains fell into two great groups in the 16S (GG II and VI) and IGS (GG I and II) analyses and three groups (G VIII, X, XII) in the $23 \mathrm{~S}$ analysis (Table 1). SG X of the combined analysis clustered 11 symbionts of soybean, including the type strain of $B$. japonicum; all fell into GG II of the $16 \mathrm{~S}$ analysis and GG I of the IGS analysis, but were positioned in different groups in the $23 \mathrm{~S}$ analysis (II, IX, X and isolated). In SG XI, all but one (SEMIA 658) of the ten strains were symbionts of soybean and fell into GG I of the IGS analysis, but occupied different great groups of the $16 \mathrm{~S}$ analysis (GG II, III and V) and four different groups of the 23S rRNA analysis (G VII, VIII, X and XII). All strains within SG XII of the combined analysis were isolated from soybean, including B. japonicum SEMIA 5080 and its putative parent SEMIA 586, and, again, they fell into different groups of each isolated ribosomal region; a similar situation was observed with the nine strains of SG XIII, which clustered the pair of B. japonicum strains SEMIA 566 and SEMIA 5079 , as well as the strain recommended as soybean inoculant in Argentina, B. japonicum SEMIA 5085. SG IV included four strains from soybean that grouped into GG III of the 16S, GG I of the IGS and G IX, X and XI of the 23 S analysis. Finally, five strains isolated from five different genera, but all belonging to the subfamily Papilionoideae, composed SG XV of the combined analysis, while strain SEMIA 543 occupied an isolated position. Again, in this second great group of the combined analysis, strains could be placed within the species $B$. japonicum, but several subgroups were clearly shown and deserve further investigation. Finally, four strains quite diverse in all ribosomal regions, SEMIA 6319, 535, 569 and 658, were clustered to GG I and II of the combined analysis at a very low level of similarity (31.9\%).
GG III in the combined analysis joined six strains, three isolated from soybean in Paraguay and showing a similarity of $42.8 \%$, all of which were placed in GG I of the $16 \mathrm{~S}$ analysis and G I of the $23 \mathrm{~S}$ analysis, showing greater differences in the IGS region. Finally, GG IV of the combined analysis joined six strains with a similarity of $31.9 \%$, also showing high similarity in the 23S (XVI), 16S (GG VII) and IGS (SG IX except for AM-P5, which was placed in SG $\mathrm{X}$ ) analyses (Fig. 1, Table 1).

\section{DISCUSSION}

Large diversity among Bradyrhizobium strains from the tropics has been reported in several studies when properties such as colony morphology, exopolysaccharides, serological reactions, intrinsic resistance to antibiotics, substrate utilization, protein profiles, presence of enzymes such as hydrogenases and multilocus enzyme electrophoresis (MLEE) profiles were considered (e.g. van Rossum et al., 1995; Moreira, 1991, 2000; Moreira et al., 1993; Boddey \& Hungria, 1997; Doignon-Bourcier et al., 1999; Chen et al., 2002). However, the diversity observed among bradyrhizobial strains is usually not reflected in 16S rRNA gene sequence analysis; therefore, few Bradyrhizobium species have been described so far. As bradyrhizobia seem to constitute a major part of the rhizobial isolates in the tropics (Norris, 1965; Moreira, 2000) and as rhizobia might be more diverse in the tropics (Oyaizu et al., 1992; Moreira et al., 1993; Urtz \& Elkan, 1996; Vinuesa et al., 1998, 2005a), a large collection of Bradyrhizobium strains would add valuable information about the diversity of ribosomal genes within the genus.

The genetic characterization in this study was performed with 119 strains from the Brazilian official culture collection SEMIA of rhizobial strains. The strains had been isolated from 33 legume species (Table 1), most from the tropics, representing nine tribes and including all three subfamilies (Supplementary Table S2). It is recognized that root nodules are generally found in members of the subfamilies Mimosoideae and Papilionoideae and are rare in the Caesalpinioideae (Allen \& Allen, 1981); indeed, in our collection, just one strain, SEMIA 6099, was isolated from a member of the Caesalpinioideae, Dimorphandra exaltata.

In previous studies, RFLP-PCR of $16 \mathrm{~S}$ rRNA genes clearly differentiated Bradyrhizobium from Rhizobium, and often B. japonicum from B. elkanii (Laguerre et al., 1996; Wang et al., 1999), as well as resolving a group of Bradyrhizobium isolates from the Canary Islands that included strain BTAi 1 (Jarabo-Lorenzo et al., 2000). In our study, 52 strains fell into two great groups, at a level of similarity of $50 \%$, including all reference strains of B. japonicum, $90 \%$ of them isolated from soybean. However, soybean strains were also present in other groups, and isolates from Paraguay, which may represent indigenous bradyrhizobia (Chen et al., 2000, 2002), were quite dissimilar from reference and type strains.

In relation to $B$. elkanii, two other clusters, joined at a similarity of $53 \%$, included reference strains, but not USDA 
$76^{\mathrm{T}}$. In addition, several strains were placed in three great groups (GG I, VI and VII) and were quite dissimilar from all type and reference strains (Table 1; Supplementary Fig. S1). The great majority of strains isolated from tropical legume species were placed in clusters related to B. elkanii, or within the new clusters. Indeed, in a previous study in which the protein profiles of isolates from the Brazilian Amazon and Atlantic forests were analysed, most (92 of 120) were clustered in a large group $(r=0 \cdot 86)$ with $B$. elkanii (Moreira et al., 1993). In contrast, bradyrhizobia isolated from the canopy tree Platypodium elegans and the lianas Machaerium milleflorum and $M$. arboretum in Panama showed higher similarity (98-99\%) to B. japonicum (Parker \& Lunk, 2000). Also, in an analysis of a large collection of indigenous rhizobia in China, no B. elkanii strains were detected (Dr Wen-Xin Chen, personal communication). In conclusion, despite the low variability reported for the $16 \mathrm{~S}$ rRNA region of Bradyrhizobium in some studies (So et al., 1994; Urtz \& Elkan, 1996; Moreira et al., 1998; Molouba et al., 1999; van Berkum \& Fuhrmann, 2000; Chen et al., 2000; Willems et al., 2001), and despite the coefficients used in some of the analyses being different, the strains from our study were joined at a very low level of similarity, $28 \%$, showing greater variability than any previous report. For example, an analysis of African indigenous soybean bradyrhizobia by RFLP-PCR with five restriction enzymes grouped the strains with a similarity of $70 \%$ (Abaidoo et al., 2000), while in strains from native leguminous species of Senegal, the similarity with five restriction enzymes was approximately $74 \%$, decreasing to $55 \%$ when a strain from Aeschynomene was included (Doignon-Bourcier et al., 1999).

The great resolving power of RFLP-PCR of the IGS has been pointed out in some studies with rhizobia (e.g. Laguerre et al., 1996) and, in a study with Bradyrhizobium strains, the region provided taxonomic information similar, but not always identical, to that obtained by DNA-DNA hybridization (Willems et al., 2001). Furthermore, the results also indicated that the genus consists of a group of four highly related genospecies (B. japonicum, B. liaoningense and two other genospecies) and at least three other genospecies, one of which is B. elkanii (Willems et al., 2001). In our study, type and reference strains of $B$. japonicum fell into a major group that included 54 strains, $59 \%$ isolated from soybean, at a final level of similarity of $55 \%$. Type and reference strains of $B$. elkanii fell into another major group that clustered 53 strains, $64 \%$ isolated from hosts other than soybean, at $44 \%$ similarity. Once again, subclusters were observed within each major group, and seven other strains resulted in a final grouping of the IGS region at a level of similarity of $27 \%$ (Table 1, Supplementary Fig. S2). As a comparison, when bradyrhizobia nodulating Senegalese legumes were analysed by PCR-RFLP of the IGS with eight enzymes, the strains were clustered at a final level of similarity of $36 \%$ (Doignon-Bourcier et al., 2000).

When variability in the 16S rRNA gene sequence is low, it has also been suggested that analysis of the $23 \mathrm{~S}$ rRNA region can be useful, as the longer fragment contains more information with a faster rate of sequence change (Olsen \& Woese, 1993; Ludwig \& Schleifer, 1994; Wang \& Martínez-Romero, 2000). Indeed, in our study, analysis of this region resulted in the largest number of differences and the strains were grouped at a very low level of similarity $(16 \%)$. At least two groups (I and XV) were quite different from the others and might represent novel species. However, in the other clusters, speciation was not clear, including strains with mixed properties of both $B$. japonicum and $B$. elkanii when the $23 \mathrm{~S}$ rRNA was compared with the $16 \mathrm{~S}$ rRNA and IGS regions. Therefore, the results from our study confirm that phylogenies of rhizobia based on $16 \mathrm{~S}$ rRNA and $23 \mathrm{~S}$ rRNA genes may be discordant (van Berkum et al., 2003).

Combined analysis with the results of several ribosomal regions has been applied to phylogeny (e.g. Ludwig \& Schleifer, 1994; Vinuesa et al., 1998; Willems et al., 2001). When Vinuesa et al. (1998) analysed the products of RFLPPCR of the 16S rRNA and IGS regions of Bradyrhizobium strains with two enzymes per region, five genotypes were obtained, at a level of similarity of $85 \%$ or higher. In our study, when the three ribosomal regions were considered, the diversity observed was considerably greater, and great groups clustered reference strains of B. japonicum and B. elkanii at similarity values of 54 and $46 \%$, respectively (Fig. 1). However, subclusters within the main groups were clearly observed and one priority is now to investigate whether they are related to subspecies, representing genetically determined clusters of strains within the species (Staley \& Krieg, 1984), whether they represent intraspecific differences or even whether they represent novel species. Several other strains were quite dissimilar, including BTAi 1, confirming previous suggestions that this strain might belong to a separate Bradyrhizobium species (So et al., 1994; Willems et al., 2001; Vinuesa et al., 1998; Jarabo-Lorenzo et al., 2000). It is interesting to remember that BTAi 1 has mixed physiological properties of Rhizobium and Bradyrhizobium, e.g. it has a fast growth rate but produces an alkaline reaction with most carbon sources (Stowers \& Eaglesham, 1983). The majority of soybean strains fell into the species B. japonicum, and most strains isolated from Brazilian legume species fell into B. elkanii or separate clusters. Combined analysis of the three ribosomal regions confirmed at least two new clusters of bacteria showing a very low level of similarity in relation to B. japonicum and B. elkanii. These clusters are not related to the other described species of Bradyrhizobium, since none of the strains showed extra-slow growth, like B. liaoningense (Xu et al., 1995), or the characteristics of B. yuanmingense, isolated from Lespedeza spp. (Yao et al., 2002), or of B. canariense (Vinuesa et al., 2005a).

The groups defined in our study for all three ribosomal regions were confirmed in another computational study aiming at investigating the stability of the clusters by introducing perturbations using subsampling techniques. The analysis was performed for 511 experiments, where each 
experiment was a combination of possibilities between restriction enzymes and ribosomal regions. The main groups as well the new clusters were confirmed using this new approach (Milagre, 2003). Our main goal is now to characterize the new clusters, and we have already started by sequencing the 16S rRNA region of the strains from this study. Our first results have confirmed relatedness of the strains with the genus Bradyrhizobium, although several of them differ in many nucleotides from other bradyrhizobia (Menna, 2005). However, combined analysis of other conserved and housekeeping genes may be necessary to define their exact taxonomic position, as has been recently shown by Vinuesa et al. (2005b) for other Bradyrhizobium strains. The strains clustered into GG IV of the combined analysis represented one exception and, although classified as Bradyrhizobium in the Brazilian rhizobial collection SEMIA, they show greater sequence similarity in the $16 \mathrm{~S}$ rRNA gene to members of Burkholderia (Menna, 2005).

In Brazil, commercial inoculants must contain the strains recommended by an official committee of rhizobiologists, and decisions on these strains are taken based on their agronomic performance in trials with several strains (Hungria et al., 2005). One important feature of the strains from this study is that they are all very effective in fixing $\mathrm{N}_{2}$ and, indeed, 43 of them are recommended as the most effective for 31 of the 33 host legumes in this study (Table 1). Furthermore, many of the strains are effective and recommended for more than one legume species, e.g. SEMIA 6156 and SEMIA 6158 are officially recommended for Crotalaria spectabilis and Canavalia ensiformis, while SEMIA 6156 is also recommended for Crotalaria juncea and SEMIA 6158 for Stizolobium atterrimum. Another interesting observation is that some strains with identical RFLP profiles of the ribosomal regions were isolated and recognized as very effective for hosts from various legume species and tribes, e.g. SEMIA 6002, 6144 and 6156 gave identical profiles for the IGS region, but were isolated from different genera and tribes, Vigna (Phaseoleae), Arachis (Aechynomeneae) and Crotalaria (Crotolarieae), respectively. The only strain isolated from a species of the subfamily Caesalpinioideae, SEMIA 6099, was also quite similar in all ribosomal regions to SEMIA 6093, isolated from Aeschynomene americana, in the subfamily Papilionoideae. Thus, our data confirm previous results obtained in the analysis of protein profiles of 171 strains belonging to 14 legume species (Moreira et al., 1993), since no evolutionary correlation was observed between bradyrhizobial clusters and host plants.

In conclusion, three ribosomal regions were analysed from a collection of strains classified as Bradyrhizobium based on morphological and physiological properties in vitro (FEPAGRO, 1999). All strains were characterized by high efficiency of $\mathrm{N}_{2}$ fixation and had been isolated from a wide range of host tropical legumes. A degree of variability never reported before has been detected, emphasizing the high level of diversity of symbiotic diazotrophic bacteria in the tropics that still remains to be determined.

\section{ACKNOWLEDGEMENTS}

The authors thank Eliane Villamil Bangel (FEPAGRO) for providing the strains and Ligia Maria O. Chueire (Embrapa Soja) for help in several steps of this work. Research described herein was partially financed by $\mathrm{CNPq}$ (Conselho Nacional de Desenvolvimento Científico e Tecnológico - PRONEX-41.96.0884.00 and 301241/2004-0). P.M. acknowledges a fellowship from CAPES.

\section{REFERENCES}

Abaidoo, R. C., Keyser, H. H., Singleton, P. W. \& Borthakur, D. (2000). Bradyrhizobium spp. (TGx) isolates nodulating the new soybean cultivars in Africa are diverse and distinct from bradyrhizobia that nodulate North American soybeans. Int J Syst Evol Microbiol 50, 225-234.

Allen, O. N. \& Allen, E. (1981). The Leguminosae: a Source Book of Characteristics, Uses and Nodulation. Madison, WI: University of Wisconsin Press.

Boddey, L. H. \& Hungria, M. (1997). Phenotypic grouping of Brazilian Bradyrhizobium strains which nodulate soybean. Biol Fertil Soils 25, 407-415.

Chen, L. S., Figueredo, A., Pedrosa, F. O. \& Hungria, M. (2000). Genetic characterization of soybean rhizobia in Paraguay. Appl Environ Microbiol 66, 5099-5103.

Chen, L. S., Figueredo, A., Villani, H., Michajluk, J. \& Hungria, M. (2002). Diversity and symbiotic effectiveness of rhizobia isolated from field-grown soybean nodules in Paraguay. Biol Fertil Soils 35, $448-457$.

Chueire, L. M. O., Bangel, E., Mostasso, F. L., Campo, R. J., Pedrosa, F. O. \& Hungria, M. (2003). Classificação taxonômica das estirpes de rizóbio recomendadas para as culturas da soja e do feijoeiro baseada no seqüenciamento do gene 16S rRNA. Rev Bras Ci Solo 27, 833-840 (in Portuguese).

Doignon-Bourcier, F., Sy, A., Willems, A., Torck, U., Dreyfus, B., Gillis, M. \& de Lajudie, P. (1999). Diversity of bradyrhizobia from 27 tropical Leguminosae species native of Senegal. Syst Appl Microbiol 22, 647-661.

Doignon-Bourcier, F., Willems, A., Coopman, R., Laguerre, G., Gillis, M. \& de Lajudie, P. (2000). Genotypic characterization of Bradyrhizobium strains nodulating small Senegalese legumes by 16S-23S rRNA intergenic gene spacers and amplified fragment length polymorphism fingerprint analyses. Appl Environ Microbiol 66, 3987-3997.

FEPAGRO (1999). Culture Collection Catalogue, 8th edn. Porto Alegre: Fundação Estadual de Pesquisa Agropecuária.

Fernandes, M., Fernandes, R. P. M. \& Hungria, M. (2003). Caracterização genética de rizóbios nativos dos tabuleiros costeiros eficientes em culturas do guandu e caupi. Pesq Agropec Bras 38, 911-920 (in Portuguese).

Fred, E. B., Baldwin, I. L. \& McCoy, E. (1932). Root Nodule Bacteria of Leguminous Plants. Madison, WI: University of Wisconsin Press.

Garrity, G. M. \& Holt, J. G. (2001). The road map to the Manual. In Bergey's Manual of Systematic Bacteriology, 2nd edn, vol. 1, pp. 119-166. Edited by D. R. Boone, R. W. Castenholz \& G. M. Garrity. New York: Springer.

Hara, F. A. S. (2003). Ecologia de rizóbia em condições ácidas e de baixa fertilidade da Amazônia. PhD thesis, Instituto Nacional de Pesquisas da Amazônia/Universidade Federal da Amazônia, Manaus, Brazil (in Portuguese).

Hungria, M., Loureiro, M. F., Mendes, I. C., Campo, R. J. \& Graham, P. H. (2005). Inoculant preparation, production and application. In 
Nitrogen Fixation: Origins, Applications, and Research Progress, vol. 4, Nitrogen Fixation in Agriculture, Forestry, Ecology, and the Environment, pp. 223-254. Edited by D. Werner \& W. E. Newton. Dordrecht: Springer.

Jarabo-Lorenzo, A., Velázquez, E., Pérez-Galdona, R., VegaHernández, M. C., Martínez-Molina, E., Mateos, P. F., Vinuesa, P., Martínez-Romero, E. \& León-Barrios, M. (2000). Restriction fragment length polymorphism analysis of $16 \mathrm{~S}$ rDNA and low molecular weight RNA profiling of rhizobial isolates from shrubby legumes endemic to the Canary Islands. Syst Appl Microbiol 23, $418-425$.

Jordan, D. C. (1982). Transfer of Rhizobium japonicum Buchanan 1980 to Bradyrhizobium gen. nov., a genus of slow-growing, root nodule bacteria from leguminous plants. Int J Syst Bacteriol 32, 136-139.

Jordan, D. C. (1984). Family III. Rhizobiaceae Conn 1938. In Bergey's Manual of Systematic Bacteriology, vol. 1, pp. 234-235. Edited by N. R. Krieg \& J. G. Holt. Baltimore: Williams \& Wilkins.

Kuykendall, L. D., Saxena, B., Devine, T. E. \& Udell, S. E. (1992). Genetic diversity in Bradyrhizobium japonicum Jordan 1982 and a proposal for Bradyrhizobium elkanii sp. nov. Can J Microbiol 38, 501-505.

Laguerre, G., Allard, M. R., Revoy, F. \& Amarger, N. (1994). Rapid identification of rhizobia by restriction fragment length polymorphism analysis of PCR-amplified 16S rRNA genes. Appl Environ Microbiol 60, 56-63.

Laguerre, G., Mavingui, P., Allard, M. R., Charnay, M. P., Louvrier, P., Mazurier, S. I., Rigottier-Gois, L. \& Amarger, N. (1996). Typing of rhizobia by PCR DNA fingerprinting and PCR-restriction fragment length polymorphism analysis of chromosomal and symbiotic gene regions: application to Rhizobium leguminosarum and its different biovars. Appl Environ Microbiol 62, 2029-2036.

Ludwig, W. \& Schleifer, K. H. (1994). Bacterial phylogeny based on $16 \mathrm{~S}$ and $23 \mathrm{~S}$ rRNA sequence analysis. FEMS Microbiol Rev 15, 155-173.

Menna, P. (2005). Filogenia de rizóbios utilizados em inoculantes comerciais brasileiros, com base no sequenciamento do gene ribossomal 16S. MSc thesis, Universidade Estadual de Londrina-Depto de Microbiologia, Londrina, Brazil (in Portuguese).

Milagre, S. T. (2003). Análise de estabilidade de cluster em uma coleção brasileira de bactérias diazotróficas do gênero Bradyrhizobium. MSc thesis, Universidade Estadual de Londrina-Depto de Engenharia Elétrica, Londrina, Brazil (in Portuguese).

Molouba, F., Lorquin, J., Willems, A., Hoste, B., Giraud, E., Dreyfus, B., Gillis, M., de Lajudie, P. \& Masson-Boivin, C. (1999). Photosynthetic bradyrhizobia from Aeschynomene spp. are specific to stemnodulated species and form a separate $16 \mathrm{~S}$ ribosomal DNA restriction fragment length polymorphism group. Appl Environ Microbiol 65, 3084-3094.

Moreira, F. M. S. (1991). Caracterização de estirpes de rizóbio isoladas de espécies florestais pertencentes a diversos grupos de divergência de Leguminosae introduzidas ou nativas da Amazônia e Mata Atlântica. $\mathrm{PhD}$ thesis, Universidade Federal Rural do Rio de Janeiro-Depto de Solos, Seropédica, Brazil (in Portuguese).

Moreira, F. M. S. (2000). Biodiversity of rhizobia from a wide range of forest leguminosae species in Brazil. In Nitrogen Fixation: from Molecules to Crop Productivity, pp. 181-182. Edited by F. O. Pedrosa, M. Hungria, M. G. Yates \& W. E. Newton. Dordrecht: Kluwer Academic. Moreira, F. M. S., Gillis, M., Pot, B., Kersters, K. \& Franco, A. A. (1993). Characterization of rhizobia isolated from different divergence groups of tropical Leguminosae by comparative polyacrylamide gel electrophoresis of their total proteins. Syst Appl Microbiol 16, 135-146.
Moreira, F. M. S., Haukka, K. \& Young, J. P. W. (1998). Biodiversity of rhizobia isolated from a wide range of forest legumes in Brazil. Mol Ecol 7, 889-895.

Nishi, C. Y. M., Boddey, L. H., Vargas, M. A. T. \& Hungria, M. (1996). Morphological, physiological and genetic characterization of two new Bradyrhizobium strains recommended as Brazilian commercial inoculants for the soybean. Symbiosis 20, 147-162.

Norris, D. O. (1965). Acid production by Rhizobium: a unifying concept. Plant Soil 22, 143-166.

Olsen, G. J. \& Woese, C. R. (1993). Ribosomal RNA: a key to phylogeny. FASEB J 7, 113-123.

Oyaizu, H., Naruhashi, N. \& Gamou, T. (1992). Molecular methods of analysing bacterial diversity: the case of rhizobia. Biodivers Conserv 1, 237-249.

Parker, M. A. \& Lunk, A. (2000). Relationships of bradyrhizobia from Platypodium and Machaerium (Papilionoideae: tribe Dalbergieae) on Barro Colorado Island, Panama. Int J Syst Evol Microbiol 50, 1179-1186.

Polhill, R. M. \& Raven, P. H. (1981). Advances in Legume Systematics. Kew, UK: Royal Botanic Gardens.

Provorov, N. A. \& Vorob'ev, N. I. (2000). Evolutionary genetics of nodule bacteria: molecular and populational aspects. Russ J Genet 36, 1323-1335.

Qian, J., Kwon, S. W. \& Parker, M. A. (2003). rRNA and nifD phylogeny of Bradyrhizobium from sites across the Pacific Basin. FEMS Microbiol Lett 219, 159-165.

Rivas, R., Willems, A., Palomo, J. L., Garcia-Benavides, P., Mateos, P. F., Martínez-Molina, E., Gillis, M. \& Velázquez, E. (2004). Bradyrhizobium betae sp. nov., isolated from roots of Beta vulgaris affected by tumour-like deformations. Int J Syst Evol Microbiol 54, 1271-1275.

Sneath, P. H. A. \& Sokal, R. R. (1973). Numerical Taxonomy. San Francisco: W. H. Freeman \& Co.

So, R. B., Ladha, J. K. \& Young, J. P. W. (1994). Photosynthetic symbionts of Aeschynomene spp. form a cluster with bradyrhizobia on the basis of fatty acid and rRNA analyses. Int J Syst Bacteriol 44, 392-403.

Staley, J. T. \& Krieg, N. R. (1984). Classification of procaryotic organisms: an overview. In Bergey's Manual of Systematic Bacteriology, vol. 1, pp. 1-4. Edited by N. R. Krieg \& J. G. Holt. Baltimore: Williams \& Wilkins.

Stowers, M. D. \& Eaglesham, A. R. J. (1983). A stem-nodulating Rhizobium with physiological characteristics of both fast and slow growers. J Gen Microbiol 129, 3651-3655.

Terefework, Z., Nick, G., Suomalainen, S., Paulin, L. \& Lindström, K. (1998). Phylogeny of Rhizobium galegae with respect to other rhizobia and agrobacteria. Int J Syst Bacteriol 48, 349-356.

Tesfaye, M. \& Holl, F. B. (1998). Group-specific differentiation of Rhizobium from clover species by PCR amplification of $23 \mathrm{~S}$ rDNA sequences. Can J Microbiol 44, 1102-1105.

Tesfaye, M., Petersen, D. J. \& Holl, F. B. (1997). Comparison of partial 23S rDNA sequences from Rhizobium species. Can J Microbiol 43, 526-533.

Urtz, B. E. \& Elkan, G. H. (1996). Genetic diversity among Bradyrhizobium isolates that effectively nodulate peanut (Arachis hypogaea). Can J Microbiol 42, 1121-1130.

van Berkum, P. \& Fuhrmann, J. J. (2000). Evolutionary relationships among the soybean bradyrhizobia reconstructed from 16S rRNA gene and internally transcribed spacer region sequence divergence. Int J Syst Evol Microbiol 50, 2165-2172.

van Berkum, P., Terefework, Z., Paulin, L., Suomalainem, S., Lindström, K. \& Eardly, B. D. (2003). Discordant phylogenies within the rrn loci of rhizobia. J Bacteriol 185, 2988-2998. 
van Rossum, D., Schuurmans, F. P., Gillis, M., Muyotcha, A., van Verseveld, H. W., Stouthamer, A. H. \& Boogerd, F. C. (1995). Genetic and phenetic analyses of Bradyrhizobium strains nodulating peanut (Arachis hypogaea L.) roots. Appl Environ Microbiol 61, 1599-1609.

Vincent, J. M. (1970). Manual for the Practical Study of Root Nodule Bacteria. Oxford: Blackwell.

Vinuesa, P., Rademaker, J. L. W., de Bruijn, F. J. \& Werner, D. (1998). Genotypic characterization of Bradyrhizobium strains nodulating endemic woody legumes of the Canary Islands by PCR-restriction fragment length polymorphism analysis of genes encoding 16S rRNA (16S rDNA) and 16S-23S rDNA intergenic spacers, repetitive extragenic palindromic PCR genomic fingerprinting, and partial 16S rDNA sequencing. Appl Environ Microbiol 64, 2096-2104.

Vinuesa, P., León-Barrios, M., Silva, C., Willems, A., Jarabo-Lorenzo, A., Pérez-Galdona, R., Werner, D. \& Martínez-Romero, E. (2005a). Bradyrhizobium canariense sp. nov., an acid-tolerant endosymbiont that nodulates endemic genistoid legumes (Papilionoideae: Genisteae) from the Canary Islands, along with Bradyrhizobium japonicum bv. genistearum, Bradyrhizobium genospecies alpha and Bradyrhizobium genospecies beta. Int J Syst Evol Microbiol 55, 569-575.

Vinuesa, P., Silva, C., Werner, D. \& Martinez-Romero, E. (2005b). Population genetics and phylogenetic inference in bacterial molecular systematics: the roles of migration and recombination in Bradyrhizobium species cohesion and delineation. Mol Phylogenet Evol 34, 29-54.

Wang, E. T. \& Martínez-Romero, E. (2000). Phylogeny of root- and stem-nodule bacteria associated with legumes. In Prokaryotic Nitrogen Fixation: a Model System for Analysis of a Biological
Process, pp. 177-186. Edited by E. W. Triplett. Wymondham, UK: Horizon Scientific Press.

Wang, E. T., van Berkum, P., Sui, X. H., Beyene, D., Chen, W. X. \& Martínez-Romero, E. (1999). Diversity of rhizobia associated with Amorpha fruticosa from Chinese soils and description of Mesorhizobium amorphae sp. nov. Int J Syst Bacteriol 49, 51-65.

Weisburg, W. G., Barns, S. M., Pelletier, D. A. \& Lane, D. J. (1991). $16 S$ ribosomal DNA amplification for phylogenetic study. J Bacteriol 173, 697-703.

Willems, A., Coopman, R. \& Gillis, M. (2001). Comparison of sequence analysis of 16S-23S rDNA spacer regions, AFLP analysis and DNA-DNA hybridizations in Bradyrhizobium. Int $J$ Syst Evol Microbiol 51, 623-632.

Woese, C. R. (1987). Bacterial evolution. Microbiol Rev 51, 221-271.

Xu, L. M., Ge, C., Cui, Z., Li, J. \& Fan, H. (1995). Bradyrhizobium liaoningense sp. nov., isolated from the root nodules of soybeans. Int $J$ Syst Bacteriol 45, 706-711.

Yanagi, M. \& Yamasato, K. (1993). Phylogenetic analysis of the family Rhizobiaceae and related bacteria by sequencing of $16 \mathrm{~S}$ rRNA gene using PCR and DNA sequencer. FEMS Microbiol Lett 197, 115-120.

Yao, Z. Y., Kan, F. L., Wang, E. T., Wei, G. H. \& Chen, W. X. (2002). Characterization of rhizobia that nodulate legume species of the genus Lespedeza and description of Bradyrhizobium yuanmingense sp. nov. Int J Syst Evol Microbiol 52, 2219-2230.

Young, J. P. W., Downer, H. L. \& Eardly, B. D. (1991). Phylogeny of the phototropic rhizobium strain BTAil by polymerase chain reaction-based sequencing of a $16 \mathrm{~S}$ rRNA gene segment. J Bacteriol 173, 2271-2277. 